\title{
Çocukta Değer Bilinci Ve Karakter Eğitimi
}

Yrd. Doç. Dr. Osman MUTLUEL

osman.mutluel@ibu.edu.tr

Boy Yayınları, Denizli 2014, 130 s.

ISBN 978-605-4954-20-9 1. BASKI

Yasin BOSTAN*

İnsan davranışlarının temeli konusu, İslam Felsefesi ve Ahlak Felsefesi açısından gizemini ve önemini, tefekkür tarihimiz boyunca hiçbir zaman kaybetmemiştir. Hatta bu alanda müstakil ilmî sahalar bile oluşmuş ${ }^{1}$ ve birçok düşünür ve ilim adamı kıymetli eserler ve makaleler kaleme almaktan geri durmamışlardır.

Sadece İslam kültüründe değil, dünya düşünce tarihi boyunca çoğu filozof ve araştırmacı, insan doğasını tanıma ve eylemlerinin aslî kaynağını bulma yolunda büyük gayret sarf etmişlerdir. Bu düşünürler, her ne kadar bazı yönleriyle kültürden kültüre değişmiş olsa da, insan olmakla elde edilen temel vasıflarımızı ortaya koymaya çalışmışlar, ortak insani değerlerimizi keşfe çıkmışlardır.

Günümüzde birçok kültür, inanış ve ideoloji, insan doğası ve eylemi üzerine zengin bir kültür mirası bırakmış olmasına, bunca tarihsel birikim ve modern psikolojinin taze bulgularına rağmen insanın bir muamma olduğu gerçeği, öylece ortada durmaktadir.

İnsan davranışlarını anlamlı ve değerli kılan «niyet» olgusunun önemini göz ardı etmeyen bir inanışın gölgesinde, insan iradesinin yönelişlerine tesir eden içsel dinamiklerin ne kadarının ilahi senaryo içerisinde insana lütfedilenler ve ne kadarının insanın bilfiil kesbi ile kaderine nakşedilenler olduğu sorunsalının sınır çizgisini belirlemek hem kelamî, hem felsefî, hem de tecrübî açıdan oldukça zor görünmektedir.

Öte yandan ahlaki davranışların kaynağını sorgulamak, insan alışkanlıklarını ve karakterini çözümlemek, «huy-mizaç-seciye» kavramları ile insan tabiatını derinlemesine irdelemek, insan doğasının potansiyellerinden olan irade ve özgürlük

\footnotetext{
* Arş. Gör., Pamukkale Üniversitesi İlahiyat Fakültesi, yasinbostan@pau.edu.tr

${ }^{1}$ Nefs İlmi, Ahlak İlmi.. vb.
} 
çatısı altında varoluşsal sorumluluklarımızı yoklamak, bu zengin mirasa katkıda bulunan kutsal anlama eyleminin bir başka veçhesidir.

İlk aşamada temeli genetik kodlarla atılan biyolojik varlığımız ile bütün yönleriyle mevcudiyetimizi ve sonradan irademiz dişında şekillendirilen coğrafi, fiziki, sosyal ve zamansal çevrenin kazanım ve tesirlerini bu süreçte dikkate almamak mümkün değildir.

Bu bağlamda yukarıda bahsi geçen atmosferin, hayatımızın erken dönemlerine ait her türlü tecrübenin, sonraki dönem benliğimizin temel sütununu oluşturan kişiliğimize tesir ve nüfuz edişi, üzerinde özenle durulması gereken diğer mühim bir noktadır.

Değer ve karakter kazanımının en hızlı ve en müsait olduğu çocukluk dönemini önemli ve hassas kılan şey, insan ömrünün değerini belirleyecek olan ve sonradan tekâmül yolunda emanet olarak üstlenilen ahlaki mükellefiyetlerin arka planında iyilik, ahlak ve fazilet yönünden hayatımızın ana karakterini oluşturmasıdır. Çocuk yaşta alınan iyi bir eğitim, insanın hayatında ihtiyaç duyacağı yegane dayanak noktası olacaktır.

Sevgi, doğruluk, dürüstlük, güvenilirlik, sorumluluk sahibi olma ve ilahi mesajların farkındalığı gibi temel insanî hasletlerle donanmış iyi bir insan, birçok toplumda amaçlanan ideal insan tipini oluşturur. Erdemli bir hayatın kod ve şifreleri ise bir nüve mahiyetindeki çocukluk yıllarımızın masumiyetinde saklı durmaktadır. Bu değerlerle beslenmemiş çocukların oluşturacağı bir toplumun geleceği ise, vicdan sahibi herkesi endişeye sevk eden bir kaostur.

$\mathrm{Bu}$ bağlamda insan hayatının önemli bir dönemini ele alan "Çocukta Değer Bilinci ve Karakter Eğitimi” kitabı, uzun yıllar eğitimle meşgul olan ve şu an bir akademisyen olarak İslam Felsefesi sahasında çalışmalar yürütmekte olan Osman Mutluel hocamızın bir ahlakçı akademisyen gözüyle anne baba ve eğitimciler açısından dikkat edilecek hususları belirlemesi yönüyle kayda değer bir eserdir.

Öte yandan Milli Eğitim Bakanlığg ve özel kurum ve kuruluşlarca, çocukların ve gençlerin duygusal ve sosyal yönlerinin geliştirilmesi konusundaki çabalar yoğunlaşmış, “Değerler Ĕğitimi” uygulamaları bu kapsamda okullarda öncelikli bir konuma getirilmiştir. Bu yönüyle tanıtımını yapmış olduğumuz çalışma, değerler eğitimi adına hem ebeveynler için, hem de bu alanda çalışma yürüten eğitimciler ve araştırmacılar 
için, konuları çeşitli yönlerden incelemesi ve basit uygulama örnekleri vermesi itibariyle başvurulabilir bir kaynak olarak görülmüştür.

Eser, öncelikle sanatların en zoru olan insan yetiştirme sanatının kaçınılmaz derecede önemli olan çocukluk aşamasına odaklanmakta; çocuk, çocuk ve aile, değer kavramı ve çocuk eğitimi, çocukta ahlaki gelişim, çocuk ve karakter eğitimi gibi konuları ele almaktadır.

Eserin dikkat çeken yönü, bu alanda yazılan diğer eserlerde çok sık rastlamadığımız, verilen örnek olay ve hikâyelerin ve genel kuramsal bilgilerin, birbirinden farklı özelliklere sahip olan her çocuk için doğrudan uygulanmasından ziyade, çocukları kendi içinde değerlendirmek gerektiği prensibini ciddiye alan, örnek olay ve hikâyeleri de ihmal etmeden evrensel ilkeleri ön plana çıkarmak suretiyle eğitime vurgu yapan bir eser görünümünde olmasıdır.

Yazar giriş bölümünde, çocuk yetiştirmenin zorluğu ve karşılaş1lan problemleri örnekleriyle açıklamakta, bu yönde eğitimciler ve anne-babalar için dikkat edilecek hususları tavsiyeler eşliğinde sunmaktadır. Anne-babalar "Nasıl bir çocuk yetiştirmek istiyorum?" sorusuna kendi dünyalarında cevap bulmuş olmalıdırlar. Bu sorunun doğru cevaplanabilmesi için öncelikle anne ve babalar kendilerine, "Ben kimim?" sorusunu yöneltmeleri gerekir. Zira kendini tanımayan ve belli bir dünya görüşü olmayan anne babaların, nasıl bir çocuk yetiştireceği konusunda çok fazla endişeleri ve gayretleri olmayacaktır. (s.14)

Dört bölümden oluşan eserin birinci bölümünde; çocuk ve aile konuları ele alınmakta, biyolojik ve psikolojik gelişim aşamaları hakkında bilgiler verildikten sonra ergenlik dönemi irdelenmekte, yaşanan sıkıntılar ve ailelerin bu zaman diliminde dikkat edecekleri hususlar dile getirilmektedir.

Kişilik gelişiminde önemli olan cinsel kimliğin k1z ve erkek çocuklarda yerleşmesi, cinsiyet gelişimi farklılıkları ve farkındalığı yönündeki cinsel eğitimin önemi inkar edilemez. Buna mukabil çocuklarda sonraki dönem hayatlarında ciddi etkisi bulunan ahlak gelişimi açısından cinsel eğitim ve kişilik gelişimine etkileri konusunun eserde dikkate alınmadığ 1 fark edilmektedir.

$\mathrm{Bu}$ alanda yapılan çalışmalarda din ve ahlak eğitimi çerçevesinde çocuklara cinsel eğitim verilmesine dair ihtiyacın gün geçtikçe artması, bu konudaki çalışmaların halen 
yeterli olmaması ve onlara duyulan gereksinim, değer ve karakter eğitimi konularına önem veren hocamızın ya müstakil bir eserde ya da eserin sonraki baskılarında bu hususu da ele alacağına dair temennimizi de paylaşmakta fayda vardır.

Bölümün son kısmında “aile” konusu ele alınmakta, aile tipleri hakkında özlü bilgiler verildikten sonra ailelerin çocuk eğitiminde dikkat edeceği hususlar maddeler halinde sıralanmaktadır. Bu maddeler genel hatlarıyla;

Çocuk eğitiminde öncelikle ebeveynlerin kendi kendilerini eğitmesi, Çocuk yetiştirmede "sabır" kavramının önemi, Cesaret ve kendine güven duygularının kazandırılması, Çocuğu tanıma ve her çocuğun bireysel özelliklerinin dikkate alındığı çocuk merkezli eğitim, Kardeşler arası ya da diğer çocuklarla kıyaslama yapmanın sakıncaları.. olarak sıralanabilir. (s.31-34)

Değer ve Çocuk ana başlığg altında değer ve ahlak gelişiminin ele alındığı ikinci bölümde “değer" kavramı genel hatlarıyla tanıtılmış;

- Dini Değerler,

- Ahlaki Değerler,

-Estetik Değerler

olarak değer çeşitleri sıralanmış, bunların yanında davranışlarımıza etki eden hazcı değer anlayışı, faydacı değer anlayışı ve mantıksal değer anlayışı tasnifiyle çeşitli değer anlayışlarına yer verilmiştir. (s.43-46)

Günlük hayatımızdan basit örneklerle konular zenginleştirilmiş, ayrıca Narsistik Kişilik özelliklerine değinilmiş ve çocukluk yıllarında başlayan bu tür bozuk kişiliklerin ortak özelliklerine dikkat çekilerek değer algısının sorunlarına işaret etmek yazarımızca uygun görülmüştür. (s.47-50)

Bölümün devamında Değer ve Vicdan Oluşumu kısmında; çocukta vicdani duygunun 8 yaşından sonra ortaya çıktığı belirtilmekte, çocukta değer yargılarıyla vicdan gelişiminin paralel ilerlediği ifade edilmektedir. (s.52) Bununla birlikte anne karnından başlamak üzere çocuğun bebeklik ve erken çocukluk dönemlerini de içine alan, ileride vicdan gelişiminin çekirdeği hükmündeki duygusal kazanımlarını aile ortamında olumlu benlik veya olumsuz benlik algısı şeklinde yüklendiği gerçeğini de ifade etmek gerekir. 
Çocuk, anne karnından itibaren sevildiğini hissetmekte, annenin olumlu-olumsuz duygu durumlarına ve o dönemde anne-babanın bebeğe dönük samimi yönelişlerine tepkiler verdiği gözlenmektedir. Çocuk, bebeklik dönemi ile birlikte aile ortamında öncelikle anne-babadan başlamak üzere sevildiğine, önemli bir varlık olduğuna dair kendisi hakkında bir kanaati yine kendisi oluşturmakta, bunun sonucunda çevrenin kendisine yaklaşımlarından değerli bir varlık olduğu inancına olumlu bir benlik algısıyla birlikte kendi kendisini yargılayarak ulaşmaktadır.

Çocukta kendisinin önemli ve değerli bir varlık olduğuna dair kanaat oluşursa, çocuk benliğinin derinliklerinde bu değer algısının katsayıları oranında hayatının kalitesini, öz sevinç ve mutluluğunu, kimlik ve kişiliğinin tutarlılığını, azmini, olaylar karşısındaki dayanıklılık ve direncini, yaptığı işlerin kalitesini bu öz yargıdan alacaktır. Aksi takdirde bahsi geçen durumların tam tersi yönde yansımaları gayet tabiîdir.

Bu bağlamda iyi, kaliteli bir aile ortamının tüm bu avantajları sağlayacak yegâne kazanım ortamı olduğunu belirtmek de faydalı olur. Sonuç olarak değer yargılarının oluşumunun arka planını anne-baba arasındaki olumlu iletişimle kurulmuş sağlıklı aile atmosferinin kuşatıcılığına bağlamak yerinde olur ki; çocukta değer yargılarının gelişiminin temelini doğru tespit etmiş olabilelim.

Eserin genelinde bu ideal aile ortamına sık sık atıfta bulunulduğu gözlenmektedir. Değer yargılarının geliştiği diğer önemli iki ortam; okul ve çevre 'ye yazar tarafından vurgu yapılmış, bunlarla ilgili günlük hayattan pek çok örneğe yer verilmiştir. (s.50-58)

Bölümün sonlarına doğru, günümüzde ailelerin zihnini meşgul eden, iyi niyetlerle kıvamını tutturmakta oldukça zorlandıkları çocuk ve özgürlük konusu göz önünde bulundurulmuş, özgürlüğün çocuğun kişiliğindeki önemi belirtilmekle birlikte özgürlügün sağlıksız verildiği çocuklarda ortaya çıkan yan etkilere karşı gerekli uyarılar da ihmal edilmemiştir. Eserde çocuk eğitiminde olması gereken ideal tablonun tasvirine dair tavsiyelerin, basit ve doyurucu bir şeklide verildiğini de belirtmekte fayda vardır. (s.58-60)

İkinci bölümün son kısmında ahlaki gelişimi etkileyen aile içi ve dışı faktörler ele alınmış, gelişimi etkileyen akıl, aileye özel gelenekler, aile içi tutarlılık, çocuk için örnek sayılacak ve rehberlik edecek model tercihi, ailenin sosyo-ekonomik durumu gibi başlica unsurlara gayet sade bir şekilde değinildiği görülmektedir. (s.61-66) 
Çocuğun dünyasında olması beklenen temel ahlaki değerlerden doğruluk, güvenilirlik, orta yolu takip etme, ölçülü olma gibi temel değer yargıları ile sınıf ortamında bunların nasıl kazanılacağı ile ilgili bir sınıf etkinliğinin örnek verilmesi bölümün sonunda ihmal edilmemiştir. (s.66-77)

Karakter eğitiminin merkeze alındığı üçüncü bölümde karakter eğitiminde dikkat edilecek hususlar tek tek ele alınırken, karakter eğitiminin aile, okul ve çevre ile birlikte yürütülmesi gerektiği ön plana çıkarılmaktadır. "Karakter eğitimi, duygu, davranışve bilgi aşamaları olan bir eğitim sürecidir. Bu aşamaların birbirinden ayırmadan beraber yürütülmesi.." gerektiği vurgulanmaktadır. (s.82) Bu eğitimin olmazsa olmaz vasfi, dinî ve ahlakî farkındalıklarla birlikte verilmesi gerektiğidir. Yazar, ailede, okulda ve çevrede karakter eğimine ayrı başlıklar altında değindikten sonra, masalın çocuk dünyasındaki önemini göz önünde bulundurulmuş, bir masal eşliğinde çocuğa karakter ve hayal gücü kazandırabilmenin fırsatları eğitimci hassasiyetiyle gayet akıcı bir şekilde sunulmuştur. (s.90-95)

Bölümün sonunda müstakil bir masal üzerinden, içeriğindeki her bir figürün temsil ettiği karakteristik özellikler sıralanarak bu figürlerin karakter analizi yapılmış, özellikle ebeveynler ve eğitimciler için istifade edilebilir bir kıvamda okuyucuya sunulmuştur. (s.95-103)

Eserin son ve dördüncü bölümünde, hepimiz için örnek model teşkil eden Peygamberimiz ve o'nun çocuk eğitiminde dikkat ettiği hususlar ön plana çıkarılmıştır. Bu hususları maddeler halinde sıralayacak olursak:

- Peygamberimizce çocukların masumiyetleri vurgulanmıştır.

- Kız çocuklarına ve kız kardeşlere pozitif ayrımcılık yapmıştır.

- Anne-babalara düşen görevleri belirtmiştir.

- Çocukların ücretle çalıştırılmalarını tavsiye etmemiştir.

- Çocukların şakadan bile olsa aldatılmaması gerektiğini söylemiştir.

- Kendisi çocuklarla şakalaşmıştır.

- Çocukların eğitimine özen göstermiştir.

- Çocukların anne-babalarının kim olduğu ve sütannelik konusu üzerinde 1srarla durmuştur 
Sonuç olarak Peygamberimizin çocuklara, henüz çocuk oldukları farkındalığı ile davrandığ1 fakat onlara değer verme hususunda bir yetişkinden ayırt etmediği, hak ettikleri ilgi, sevgi ve saygıyı Peygamberimizden gördüklerini özellikle belirtmek gerekir.

Maalesef anne-babaların çocuk eğitiminde çok defa yaptığı ciddi bir formasyon hatası ise onların gelişim dönem ve özelliklerini dikkate almadan, sanki bir yetişkinmiş gibi davranmalarını bekleyerek onları kendi sınırlarının üstünde bir gelişim sürecine zorlamaktır. Bu noktada peygamberimiz bizim için eşsiz bir örnek teşkil etmekte, onun çocuklarla iletişim ve hukukundan alacağımız sayısız dersler olduğunu belirtmekte yarar vardir.

Gayet sade bir dille, güncel örneklerle dolu eserden, özellikle ve öncellikle çocuk yetiştirmeyi önemseyen ebeveynler ve bu alanda çalışma yapan eğitimciler ve araştırmacıların istifade edebileceğini, kolay anlaşılan, mütevazı ancak faydalı bir eser olduğunu, yazarın akıcı bir üslup kullandığını söylemek mümkündür. 